1951) and for preparing and distributing the papers and publishing the resolutions of the symposium. The admission of the Pacific Science Association to consultative arrangements with Unesco was approved by the sixth session of the general conference of Unesco (June-July 1951).

\section{Museums and Education}

IN the January issue of the Museums Journal, Dr. D. A. Allan (of the Royal Scottish Museum, Edinburgh), who was director of the seminar on "Museums and Education" held at Brooklyn Museum, New York, during September 14-October 14, 1952, describes the work and activities of that important gathering. In all, there were thirty-eight members from twentyfour member countries, and the seminar was held under the auspices of the United Nations Fducational, Scientific and Cultural Organization. It was agreed at the outset that museums have to save traditions and preach standards in a world where both are threatened. With labels and sympathetic guidelecturers, there would appear to be no subject involving three dimensions that a museum cannot teach. Books and museum displays were regarded as complementary, but museums can make the great immediate appeal. Many speakers stressed that the development of the emotions is an important element in an individual's education and that here the art museum can achieve much by encouraging sensitivity, response and inspiration. From this the discussions emphasized, first, the value of atmosphere in the individual museum and, secondly, the value of a museum as a point of infection for its community. Museum services must be qualitative rather than quantitative, and warnings were expressed on the inadvisability of expert museum chiefs having to devote valuable time to obtaining financial support and the common fallacy that attendance figures reflect services given. The resolutions passed by the seminar stated the unanimous conviction of the value of museums and appealed for the fullest support for them as educational, cultural and recreational centres.

\section{Calendar Reform}

AT the first meeting of the British Section of the World Calendar Association -(20 Buckingham Street, London, W.C.2), which was held in London on October 17, Sir Harold Spencer Jones, the Astronomer Royal, gave a lecture entitled "The Calendar, Past, Present and Future". He began by pointing out that the difficulties in devising. a satisfactory calendar have been due to the incommensurability of the three natural periods of time, the day, the month and the year, and he followed with a short survey of the various calendars-Egyptian, Babylonian, Greek, Jewish, Roman, Gregorian and Mahommedangiving a brief reference to the confusion introduced by these different systems. In general, Sir Harold favours the adoption of the world calendar, which has the merit of being simple, stable and perpetual (see Nature, 169, 961 and 1083 ; 1952). In this scheme, the year is divided into four equal quarters of ninetyone days, which would leave a day over in normal years and two days in leap years. Each quarter is divided into thirty-one, thirty and thirty days respectively, commencing with a Sunday and ending with a Saturday, and containing exactly thirteen weeks, the second and third months beginning on Wednesday and Friday, respectively. As there would be a day left over in normal years, this would follow December 30 and be named 'world day'; in leap years the other extra day would come in between the first and second halves of the year and be named 'leap day', and each of these days would be a world holiday. Religious objections which have been advanced against the scheme are not considered insuperable, and Sir Harold expressed the hope that the scheme, which is to be discussed by the United Nations Organization, will be seriously considered on its merits. He ended with an appeal for the widest measure of support for the world calendar, a reform which will only be possible if there is a vigorous campaign to expound its advantages to the ordinary man.

\section{Careers in the Petroleum Industry}

A NUMBER of booklets dealing with careers and prospects for professional men in the Royal Dutch/ Shell Group of Oil Companies have been published by the Shell Petroleum Co., Ltd. (St. Helen's Court, London, E.C.3), and they can be recommended particularly to parents, headmasters and potential candidates for appointments in this field. In one, "Careers in the Petroleum Chemical Industry" (pp. $22 ; 1952$ ), the subject-matter is divided into two sections, general information and careers. The former gives details of the Group's organization and work, incidence of National Service, conditions of pay, promotion, service overseas and how to apply for employment. Under the section on careers is explained the growth of this modern phase of petroleum technology, the marketing of special products, and areas where chemical manufactures are concentrated, concluding with a brief description of research and development laboratories, the production of intermediates and marketing areas. Another brochure, "Careers in the Royal Dutch/Shell Group" (pp. 82 ; second edition, 1952), goes into the oil industry in more detail, embracing the range of different occupations in the industry as a whole and covering all initial information that anyone having this vocation in mind will benefit by careful perusal. These publications are lavishly illustrated in a manner that, combined with excellent texts, brings home to the reader in straightforward wording the vast ramifications of this industrial scene as it exists to-day all over the world; no less are the great opportunities awaiting those who lean either to administrative or, perchance, more adventurous activities at home or overseas.

\section{Guide to Chemicals used in Crop Protection}

THE number and variety of chemicals used in plant protection from insect pests, diseases and weeds has vastly increased during recent years. The nomenclature of the many compounds employed is most involved, and few would claim to be thoroughly conversant with them, while the rapidity with which progress in the subject continues renders it impossible for the text-book writer to keep abreast with the latest developments. Many will therefore welcome the issue by the Canadian Department of Agriculture of a publication entitled "Guide to the Chemicals used in Crop Protection", by H. Martin and J. R. W. Miles (pp. 236 ; from the Science Service Laboratory, University of Western Ontario, Sub Post Office, London, Ontario ; 1952). 'This mimeographed publication gives a concise account of some 177 chemicals, including in each case their full structural formula, history, manufacture, properties (physical, chemical and biological), formulation and method of analysis. The arrangement is alphabetical and in loose-leaf form to facilitate addition or revision. An index is 